\title{
Interest Rate Liberalization and Capital Adequacy in Models of Financial Crises
}

\author{
Ray Barrell ${ }^{*}$, Dilruba Karim ${ }^{\dagger}$ and Alexia Ventouri ${ }^{\ddagger}$
}

\begin{abstract}
:
We characterize the effects of interest rate liberalization on OECD banking crises, controlling for the standard macro prudential variables that prevail in the current literature. We use the Fraser Institute's Economic Freedom of the World database. We test for the direct impacts of interest rate liberalization on crisis probabilities and their indirect effects via capital adequacy. Over the period 1980 - 2012, we find that interest rate liberalization has a crises reducing effect, and it appears that the beneficial effects work by strengthening capital buffers. We also show that when controlling for liberalization, capital adequacy and liquidity, the main driver of financial crises is property price growth. Our results invariant when we control for alternative sensitivity tests for robustness purposes.
\end{abstract}

JEL classification: C52; E58; G21; G28

Keywords: Banking crises; Logit; Capital adequacy; Interest rate deregulation; Economic freedom indexes

Acknowledgements: The Authors wish to thank the conference participants at the 5th International Conference of the Financial Engineering and Banking Society (FEBS) held in Nantes in June 2015 for helpful comments and discussion.

* (Corresponding author): Economics and Finance Department, Brunel University London, Kingston Lane, Uxbridge, UB8 3PH (United Kingdom); Tel: +44-1895-265430 Email: ray.barrell@ brunel.ac.uk.

$\dagger$ Economics and Finance Department, Brunel University London, Kingston Lane, Uxbridge, UB8 3PH (United Kingdom); Tel: +44-1895-265955 Email: dilly.karim@brunel.ac.uk.

* Economics and Finance Department, Brunel University London, Kingston Lane, Uxbridge, UB8 3PH (United Kingdom); Tel: +44-1895-267165 Email: alexia.ventouri@ brunel.ac.uk. 


\section{Introduction}

If we are to learn enduring lessons from the sub-prime crisis we need to know whether it was in some way unique, or whether it shared features in common with earlier banking crises. Recent research focusing on the macro determinants of crises provides evidence that OECD banking instability can be explained by capital adequacy, liquidity, house price and current account imbalances (Barrell et al. 2010; 2013a). However by definition, these impacts are conditional on the regulatory environment under which banks operate. Over the last three decades the regulatory architecture has experienced major transformations, yet there is little consensus as to how these changes have affected bank risk taking behavior and hence crises probabilities. Given the established links between financial liberalization, crises and efficiency (Barth et al. 2006; Agoraki et al. 2011; and Chortareas et al. 2012), their interaction with regulatory capital becomes paramount. Regulation of both deposit and lending rates was common, in the OECS during the 1980s and 1990s (Edey and Hviding, 1995). For example, Regulation Q in the U.S. enforced interest rate controls for over 50 years on the premise that controlling deposit rate competition would allow banks to earn normal profits without resorting to risky loans and this in turn mitigated the need for regulatory capital.

This paper constitutes the first attempt, to our knowledge, to explicitly characterize the effects of interest rate deregulation on OECD banking crises between 1980 and 2012. Our approach combines both the macro (prudential) and micro (Chortareas et al. 2013) strands of the literature on banking stability. To capture these dynamics we utilize the economic freedom index drawn from the Fraser Institute. Although the index characterizes different aspects of financial 
liberalization, not all of these are relevant to the $\mathrm{OECD}^{1}$. We focus explicitly on interest rate restrictions which changed under formal liberalization programs in many OECD economies during the 1980s and 1990. We test for the direct impacts of interest rate liberalization on crisis probabilities and their indirect effects via capital adequacy.

Our results show that interest rate liberalization has a crises reducing effect in the OECD. Moreover, the beneficial effects of interest rate deregulation, or the removal of financial repression (see Reinhart, 2012) seems to work by strengthening the effects of capital buffers. We also show that when we control for liberalization, capital adequacy and liquidity, the main driver of financial crises is property price growth. Other factors do not seem to be significant, and increased financial repression after the crisis may have marginally increased the probability of future crises.

The reminder of the paper is organized as follows: Section 2 reviews the relevant literature. Section 3 presents the empirical methodology and the data. Section 4 discusses the empirical results, and Section 5 concludes.

\section{Banks and the factors driving bank crises}

Banking crises emerge because banks do not have enough liquidity to meet depositors' needs and cannot access the wholesale market, or because loan losses have built up to the point where capital is exhausted. Hence, a relatively simple banking crisis model must include the liquid asset and capital ratios as explanatory variables. In addition, we should control for macro factors that affect the variability of loan losses and deposits. Before discussing the standard

\footnotetext{
${ }^{1}$ For example, private sector credit controls as defined by the fiscal deficit to gross savings ratios would be of little concern in OECD economies during our sample period. Similarly central government ownership of banks captured by the $\%$ of deposits held in government banks would be low in market based OECD banking systems.
} 
controls used in the literature, we note an important omission in these studies: none of them consider the impact of interest rate controls on bank behavior and performance. The pace of financial liberalization increased over the last three decades, particularly during the 1980s and 1990s. For example, the deregulation process in the European Union (1990s) considerably liberalized banks' structural and conduct rules ${ }^{2}$. This was accompanied by a parallel increase in prudential regulation, particularly in relation to a minimum capital adequacy.

Crisis prediction studies using contemporaneous datasets such as Demirguc-Kunt and Detragiache $(1998 ; 2005)$ cannot be classed as true early warning systems ${ }^{3}$. Hence Barrell et al. (2010) use lagged data and focus on the relatively homogeneous OECD banking system. In this context they show that capital adequacy, liquidity, property prices and current account deficits supersede traditional macro variables as crisis determinants. The lag structure of these models ensures true early warning properties and explanatory power within and out-of-sample is high (see Barrell and Karim, 2013b). In this paper, we continue with the Barrell et al. (2013b) model but recognise it is contingent on the degree of liberalization in each banking sector. Before turning to our interest rate variable, we briefly summarize the key explanatory variables in our base line model.

Crises are often the result of poor quality lending. A boom in real estate prices inflates the availability of collateral causing lending to be excessive and credit to be mispriced (the financial accelerator). When prices fall from unsustainable levels, this process goes into reverse, sharply tightening credit conditions and overextended borrowers have strong incentives to default. Reinhart and Rogoff (2008) suggest that property price developments can change crisis probabilities, and Barrell et al. (2010) confirm this.

\footnotetext{
${ }^{2}$ See, for example, the banking Directives enacted in the EU, as part of the Single Market Programme.

${ }^{3}$ These studies also rely on heterogeneous country sets and so the wide country coverage limits the explanatory data available for inclusion.
} 
Widening current account imbalances have been common forerunners of banking crises in the OECD (Barrell et al., 2013a). They may be accompanied by monetary inflows enabling banks to expand credit excessively which inflates asset prices in an unsustainable manner. ${ }^{4}$ These trends may be exacerbated by lower real interest rates. The existence of a current account deficit also indicates a shortfall of national saving over investment and hence a need for the banking sector to access the potentially volatile international wholesale market.

Other factors that affect loan losses are discussed extensively in Demirguc-Kunt and Detragiache (1998; 2005), Beck et al. (2006) and Barrell et al. (2010). They include real GDP growth, M2/ Foreign exchange reserves, and inflation which capture macroeconomic developments that affect banks' asset quality. Rapid credit growth may indicate lax lending standards and trigger asset booms. Loose monetary policy, given by the short term real interest rate can have the same effect. Fiscal deficits often affect the risk of crises by overheating the economy and because they reduce the scope available to recapitalise banks, making systemic crises more likely ${ }^{5}$.

Existing research provide strong evidence on the link between financial liberalization and various aspects of bank performance. Economic freedom indexes have been associated with efficiency (Chortareas et al. 2011), bank ratings (Pasiouras et al., 2006), and regulatory structure (Demirguc-Kunt et al., 2004; Barth et al., 2006; Chortareas et al., 2012). A common thread that emerged from these studies is that a high degree of liberalization boosts bank efficiency, reduces corruption in lending, or lowers banking system fragility. However, in these studies the index is

\footnotetext{
${ }^{4}$ In addition foreigners may cease to be willing to finance deficits in domestic currencies if they consider their assets are vulnerable to monetization via inflation, and such a cessation can disrupt asset markets and banks' funding. See Haldane et al. (2007) for an assessment of the impact of such a hypothetical unwinding in the US

${ }^{5}$ Fiscal difficulties were not present prior to the subprime crisis but emerged afterwards, as the economy slowed and authorities had to recapitalize banks.
} 
used of a general control variable. It is only recently that empirical studies have focused on specific aspects of economic freedom/liberalization and governance effectiveness in banking performance (Chortareas et al., 2013). Such studies which isolate the different impacts, confirm the importance of factors such as financial liberalisation, including interest rate deregulation, on bank efficiency.

There are several channels by which interest rate controls may affect crisis probabilities. Situations where governments control deposit and/or lending rates (which are captured by our index), will change the scope and riskiness of banks' balance sheets and hence the role of capital. For example, in situations where there are deposit rates ceilings, a rise in the policy interest rates will cause a shortage of bank deposits as funds move elsewhere. As a result of the disintermediation, banks may change their scope of operations and move into securitization to increase non-interest income. Therefore, interest rate regulation is likely to decrease bank efficiency in the manner that Berger et al. (2008) describe. Since systemic risk will increase, the role of regulatory capital becomes more important. Conversely, when deposit rates are deregulated banks can revert to traditional lending, which is subject to normal regulatory capital rules so the marginal benefit of capital is reduced (Hellmann et al., 2000), and crisis probabilities should decline.

Similarly, controls on lending rates may induce banks to find other ways to utilise their funds. To maintain profits banks may increase their off balance sheet positions without concurrently increasing capital, and such disintermediation may increase systemic risk and hence crisis probabilities. When lending rates are market driven, the quantity of loans on banks' balance sheet will increase, but they are more likely to be protected by regulatory capital. Hence, interest rate regulation and capital are likely to influence crisis probabilities both directly and 
jointly (Cecchetti and Kohler, 2014). No systematic attempt exists to explicitly measure the impact of interest rate deregulation directly on crisis probabilities and indirectly via capital adequacy and this is the task that we pursue in the following sections.

\section{Methodology and data}

We utilize the logit model which has been a standard approach for crisis prediction (Demirguc-Kunt and Detragiache, 2005; Davis and Karim, 2008, Barrell et al., 2010; 2013,a,b). The logit estimates the probability that a banking crisis will occur in a given country with a vector of explanatory variables $\left(X_{i t}\right)$. The banking crisis variable $\left(Y_{i t}\right)$ is a zero-one dummy that takes the value of one at the onset of crisis. The logistic estimator is given by:

$$
\operatorname{Pr} o b\left(Y_{i t}=1\right)=F\left(\beta X_{i t}\right)=\frac{e^{\beta^{\prime} X_{i t}}}{1+e^{\beta^{\prime} X_{i t}}}
$$

where, $\beta$ is the vector of unknown coefficients and $F\left(\beta^{\prime} X_{i t}\right)$ is the cumulative logistic distribution. The log likelihood function is given by:

$$
\log _{e} L=\sum_{i=1}^{n} \sum_{t=1}^{T}\left[\left(Y_{i t} \log _{e} F\left(\beta^{\prime} X_{i t}\right)\right)+\left(1-Y_{i t}\right) \log _{e}\left(1-F\left(\beta^{\prime} X_{i t}\right)\right)\right]
$$

Coefficients show the direction of the effect on crisis probability, although their magnitudes are conditional ${ }^{6}$ on $X_{i t}$. We include a constant to allow for the hypothesis that crisis probabilities can be exogenous.

To assess the informational value of our variables we use the area under the (AUC) Receiver Operating Characteristic (ROC) curves which test the "skill" of binary classifiers and hence can be used to discriminate between competing models. Probabilistic forecasts can be

\footnotetext{
${ }^{6} B_{\mathrm{i}}$ represents the effect of $X_{\mathrm{i}}$ when all other variables are held at their sample mean values.
} 
classified for accuracy against a continuum of thresholds, generating true positive and true negative rates ${ }^{7}$. In the terminology of ROC analysis the two variables of interest are the true positive rate (sensitivity of the discriminator) and the false positive rate (1-specificity) ${ }^{8}$. An AUC of 0.5 is equivalent to a "naïve" estimator that replicates a random coin toss, whilst an AUC above 0.5 implies the model adds value in terms of the ability to call crises correctly with low false negative rates.

Our dataset includes 23 systemic and non-systemic crises in OECD countries. The crises between 1980 and 2003 are from Barrell et al. (2010): Canada (1983), Denmark (1987), Finland (1991), France (1994), Italy (1990), Japan (1991), Norway (1990), Sweden (1991), the UK (1984, 1991, 1995) and the US (1988). In extending the estimation further to 2008 we rely on Laeven and Valencia (2010) who classify crises in the US, the UK, Belgium, France, Germany, Denmark, Spain, Sweden (marginally) and the Netherlands. We date crises in these countries in 2008 with the UK and US having distinct crises in both 2007 and 2008. We evaluate our model using forecast tests for 2009 to 2012, with crises dated by Laeven and Valencia (2012) in Germany and Denmark in 2009 and Spain in 2011.

As discussed in Section 2, the variables included in our model are: real GDP growth, inflation, M2/ Foreign Exchange Reserves, real interest rates, fiscal surplus/GDP ratios, the current account/ GDP and real domestic credit growth. ${ }^{9}$ We follow Barrell et al. (2010) and include unweighted bank capital adequacy and bank narrow liquidity as well as real house price

\footnotetext{
${ }^{7}$ Correspondingly false positive and false negative rates are also generated.

${ }^{8}$ For a recent example of ROC curve usage in the context of crises, see Barrell et al. (2013b) and Schularick and Taylor (2012).

${ }^{9}$ We do not include certain Demirguc-Kunt and Detragiache (1998; 2005) variables because they are irrelevant to OECD countries. For example, GDP per capita is broadly comparable across OECD countries, while virtually all OECD countries have some form of deposit insurance scheme. Variations in the level of credit/GDP (as opposed to credit growth) may reflect the differing nature of the financial system in OECD countries (i.e. bank versus market dominated) rather than the risk of crisis, and we exclude this variable as well.
} 
growth. The data are from the IMF's IFS database ${ }^{10}$, with the following exceptions: house prices are from the BIS database and unweighted capital adequacy is obtained from the OECD Bank Income and Balance Sheet database (except for the UK, where data are from the Bank of England).

Data on financial liberalization are collected from the Fraser Institute Annual Reports ${ }^{11}$. The Fraser Institute's Economic Freedom of the World index allows us to explicitly focus on interest rate deregulation (IRR) variable which is constructed using data on credit-market constraints and regulations, available through the World Bank. This variable ranges between 0 and 10 , where greater values indicate more liberalization. In particular, countries in which interest rates are determined by the market, the monetary policy is stable and real deposit and lending rates are positive receive higher ratings.

\section{Results}

Our testing strategy involves the estimation of a baseline model (without the effect of interest rate regulation) and assessing its information content. The model is then re-estimated with the interest rate regulation effects and changes to the estimates and information content are noted. Finally, we test for the interaction of interest rate regulation and capital since these may

\footnotetext{
${ }^{10}$ We use narrow liquidity derived from IFS rather than the broad measure provided in the OECD Bank Income and Balance Sheet database. Narrow liquidity is defined as a sum of banks' claims on general government and the central bank, while total assets comprise foreign assets, claims on general government, central bank and private sector.

${ }^{11}$ There exist two major attempts to measure economic freedom, namely the Economic Freedom of the World Annual Reports produced by the Fraser Institute and the Index of Economic Freedom created by the Heritage Foundation and the Wall Street Journal. Because data provided by the Heritage foundation are limited in the time dimension, we are unable to test this in our model.
} 
both act as substitutable macroprudential tools (Hellmann, et al., 2000; Cecchetti and Kohler, 2014).

\subsection{The Baseline vs Interest Rate Regulation Models}

A priori we do not assume the dominance of any explanatory variables, since each contributes to a separate hypothesis on the causes of crises. We rely on nested testing of a logit model using a general to specific approach to obtain parsimony. Unlike Demirguc-Kunt and Detragiache (2005), all variables are lagged at least one period to provide a true early warning model. We follow Barrell et al (2010) and lag house prices by three years while AIC tests suggest that for other variables the appropriate lag length should be set at one. In all our experiments the AUC is used as a choice criterion, and we find more parsimonious models have similar information content to general ones. This suggests that many of the structural variables we include do not enhance our early warning system for crises. Below we discuss the different parsimonious specifications that we obtain, although results for the non-significant variables are presented in Appendix A.

<Insert Table 1 about here>

Table 1 presents the results for our baseline model versus the model that contains the effects of interest rate liberalization. As in the previous experiment, most of the macroeconomic control variables (including GDP growth, credit growth and real interest rates) do not contain 
information and are not significant crisis predictors. However, real house price growth and bank narrow liquidity/assets are significant in all specifications.

The interesting result concerns the elimination of capital once interest rate deregulation is introduced and the information content search (AUC) is repeated. Whilst both capital and interest rate liberalization have a negative coefficient and therefore independently reduce the likelihood of crisis, the contrast between models 1 and 3 seems to confirm the substitutability of interest rate liberalization and capital. This result appears to support the view that removal of deposit and lending rate controls allows banks to reduce their risky off-balance sheet positions and thus the importance of regulatory capital is reduced.

That interest rate liberalization effectively substitutes for the role of capital does not mean that capital contains no informational value. Indeed, a comparison of the area under the curves between the baseline model (including capital) and model 3 shows that the elimination of capital reduces the AUC (from 0.785 to 0.774 ). In other words, interest rate liberalization alone may not be able to explain all crises because some of these independently arise from a lack of capital. Therefore, although model 3 does capture the independent effect of interest rate deregulation its informational value is reduced because it cannot capture the direct crisis reducing effects of capital. This is confirmed by the AUC of model 2 which is identical to the AUC of the baseline model.

As it is clear that interest rate liberalization and capital adequacy have related effects on crisis probability, it is reasonable to test their interaction. Table 2 compares the estimates for the baseline model and the model which interacts capital with interest rate liberalization. The coefficient on the interaction term is negative and significant. Moreover, capital and interest rate 
regulation not significant in this experiment as independent variables, suggesting that interest rate deregulation strengthens the defensive role of a given level of capital.

<Insert Table 2 about here>

The interaction effect clearly increases the predictive power of the early warning system as can be seen by the AUC which increases from 0.785 to 0.792 . In terms of our selection criteria we would therefore choose the interaction model as the preferred explanation of OECD banking crises. In the next sections we evaluate the model performance and subject it to various robustness tests.

\subsection{In-sample and forecast performance}

We evaluate the forecast performance of our preferred interaction model against the baseline version using the in- and out- of sample crisis call rates. Between 1980 and 2008 our insample frequency of crises is 0.0631 . A predicted probability in excess of this is classed as a 'correct call' ${ }^{, 2}$. On this basis our interaction model called 11 out of 12 crises ( $91 \%$ success rate) in the sub-prime period, with only one missed crisis in Germany. The crises that were correctly identified are Belgium, Netherlands, Italy, Denmark, Sweden, France, Spain, UK and US (the last two countries being classed as having two distinct crises). One can argue that the German crisis did not follow from domestic problems, but rather from excessive exposure to US sourced MBSs. There were only two false calls, which occurred in Canada, where the combination of an

\footnotetext{
${ }^{12}$ Assuming it occurred either in the crisis year or the preceding year.
} 
oligopolistic banking system, a well-organized central bank and close knowledge of US mortgage markets resulted in lower systemic risk.

Out of sample performance is perhaps more revealing. Laeven and Valencia (2012) suggest that there were three systemic crises after 2008: Germany (2009), Denmark (2009) and Spain (2011). Our model fails to call Germany but can detect the other two crises. The true crisis call rate is $67 \%$ whilst the false crisis call rate ${ }^{13}$ is just under $40 \%$, $\%$, but these are once again heavily concentrated in Canada and to a lesser extent UK and France. Given the good forecasting performance of our preferred model we next turn to examine the marginal contributions of the explanatory variables to crises in the OECD.

\subsection{The relative importance of factors contributing to crisis incidence}

It is useful to examine the relative contributions of factors that have affected the incidence of crises in our sample period. This involves calculating the marginal effects (MARG) of each variable across time period and country and using these to assess the changes in probabilities indicated by the model. For each variable $(i)$ in each country $(j)$ and each time period $(t)$ we calculate the proportional contribution $\left(\right.$ Contrib $\left._{i, j, t}\right)$ of the factor $X_{i, j, t}$ to the change in predicted probability by calculating:

$\operatorname{Contrib}_{i, j, t}=\operatorname{MARG}_{i, j, t} \times\left(X_{i, j, t}-X_{i, j, t-1}\right)$

\footnotetext{
${ }^{13}$ There were 22 false crisis calls, with the largest number being in Canada (4) in 2009 (8 out of 14).
} 
In table 3 the average contributions across countries are reported for each decade. The most striking result is that house price appreciation in the OECD was the largest contributor to systemic risk during the 1980 s and 2000s. During the 1980s increases in risky mortgages were partially offset by interest rate liberalization and bank liquidity but inadequacies in capital elevated crisis risk.

$<$ Insert Table 3 about here>

In the 1990s the decline in capital ratios was the major factor driving changes in crisis incidence and regulation had no overall effect. In the 2000 s the decline in liquidity contributed about 40 per cent to the change in probabilities whilst house price growth was also a major factor. The reversal of liberalization around the sub-prime crisis in some OECD countries means that this variable had a minor impact on the probability of crises, raising it slightly.

\subsection{Robustness checks}

In this section, we present a variety of additional estimates to examine the robustness of our results. These tests deal with the sensitivity of our results when (i) dropping the systemic crises countries individually, (ii) relaxing the assumption of the one year lag structure, and (iii) estimating the results up to the 2006 sub-prime.

In particular, we re-estimate the logit equation from Tables 1 and 2 using a number of alternative procedures. Following Barrell et al. (2010), we allow for the possibility that our results are driven by extreme volatility in our independent variables that is caused by systemic 
crises. By removing the major systemic crises from our sample and re-estimating the model we can confirm its robustness even in the absence of systemic events. This results in the deletion of the UK, the US, Japan, Norway, Finland and Sweden individually and the US and Japan together to accommodate the high degree of contagion between their banking systems. The estimations in Table 4 show that our results remain virtually the same as those discussed in Section 4.1. Secondly, to confirm whether our results rest on the assumption of the one year lag structure, we allow for the possibility that our independent variables started influencing crises probabilities two years prior to their onset. As shown in Table 5 this amendment does not change the results to any great extent. The global magnitude of the sub-prime crisis is well known and it could be argued that our estimation parameters arise from the inclusion of this episode in our sample. To check that our result can be applied to the OECD from the 1980s onwards we terminate our sample at 2006. Table 6 shows that our results remain robust indicating interest rate regulation should be an important policy issue.

<Insert Tables 4-6 about here>

\section{Conclusion}

We show that over the last 35 years interest rate liberalization had a crisis reducing effect in the OECD alongside capital, liquidity and current account surpluses. On the other hand, property price growth consistently raised crisis risk. Our results are robust to a variety of alternative estimation checks, including country eliminations and exclusion of the sub-prime episode. 
It is often thought that liberalization is associated with an increased incidence of financial crises. Our results show this is not always the case; financial liberalization cannot be related to systemic risk in a generic way. Liberalization encompasses many different channels by which bank behavior may be affected, ranging from general law and order to particular restrictions on banking activity. When we test interest rate regulation as a specific indicator of liberalization we find it has a crisis reducing effect due to its interaction with capital adequacy. The removal of interest rate controls appears to increase the marginal benefit of regulatory capital which reduces systemic risk.

These results are of policy interest, especially in the aftermath of the sub-prime crisis where regulators have leant toward increased financial repression in order to limit the way in which banks intermediate funds. The main forms of liberalizations have been reductions on constraints of activities and products, in the presence of less rigorous capital and liquidity requirements. When house prices continue to rise, increased restrictions on bank activity may be counterproductive. From a policy perspective, regulators should monitor future house price dynamics which they may need to mitigate. In addition, the promotion of market based interest rates may yield benefits in terms of financial stability. 


\section{REFERENCES}

Agoraki, M., Delis, M., Pasiouras, F., 2011. Regulations, competition and bank risk-taking in transition countries. Journal of Financial Stability 7(1), 38-48.

Barrell, R., Davis, E. P., Karim, D., Liadze, I., 2010. Bank regulation, property prices and early warning systems for banking crises in OECD countries. Journal of Banking and Finance 34, 2455-64.

Barrell, R., Davis, E. P., Karim, D., Liadze, I., 2013a. Off balance sheet exposures and banking crises in OECD countries. Journal of Financial Stability 9(4), 673-681.

Barrell, R., Karim, D., 2013b. The role of capital, liquidity and credit growth in financial crises in Latin America and East Asia. LSE financial markets group special papers 217.

Barth, J.R., Caprio, G., Levine, R., 2006. Rethinking Bank Regulation: Till Angels Govern. Cambridge University Press, New York.

Beck, T., Demirgüc-Kunt, A., Levine, R., 2006. Bank concentration, competition and crises, first results. Journal of Banking and Finance 30, 1581-1603.

Berger, A.N., DeYoung, R., Flannery, M.J., Lee, D. and Oztekin, O., 2008. How do large banking organizations manage their capital ratios?. Journal of Financial Services Research 34, 123149.

Cecchetti, S. and Kohler, M., 2014. Why capital adequacy and interest rate policy are substitutes (and when they are not). International Journal of Central Banking 10(3), 205-231.

Chortareas, G., Girardone, C., Ventouri, A., 2011. Financial frictions, bank efficiency and risk: Evidence from the Eurozone. Journal of Business, Finance and Accounting 38, 259-287.

Chortareas, G., Girardone, C., Ventouri, A., 2012. Bank supervision, regulation, and efficiency: Evidence from the European Union. Journal of Financial Stability 8, 292-302. 
Chortareas, G., Girardone, C., Ventouri, A., 2013. Financial freedom and bank efficiency: Evidence from the European Union. Journal of Banking and Finance 37(4), 1223-1231.

Davis, E.P., Karim, D., 2008. Comparing early warning systems for banking crises. Journal of Financial Stability 4, 89-120.

Demirguc-Kunt, A., Detragiache, E., 1998. The determinants of banking crises in developed and developing countries. IMF Staff Paper 45(1).

Demirguc-Kunt, A., Laeven, L., Levine, R., 2004. Regulations, market structure, institutions and the cost of financial intermediation. Journal of Money, Credit and Banking 36, 593-622.

Demirgüç-Kunt, A., Detragiache, E., 2005. Cross-country empirical studies of systemic bank distress: A survey. IMF Working Papers 05/96, International Monetary Fund.

Edey, M., Hviding, K., 1995. An assessment of financial reform in OECD countries. OECD working paper, No 154 .

Fraser Institute, 2012. Economic Freedom Dataset. Economic Freedom of the World. Annual Report.

Haldane, A., Hall, S., Pezzini, S., 2007. A new approach for assessing risks to financial stability. Bank of England Financial Stability Paper 2.

Hellmann, T.F., Murdock, KC, Stiglitz, J., 2000. Liberalization, moral hazard in banking, and prudential regulation: Are capital requirements enough?. American Economic Review 90, $147-165$.

Laeven, L., and Valencia, F., 2010. Resolution of banking crises: The good, the bad, and the ugly. IMF working paper 10/146.

Laeven, L., and Valencia, F., 2012. Resolution of banking crises. IMF Working Paper WP/12/146. 
Pasiouras, F., Chrysovalantis, G., Zopounidis, C., 2006. The impact of bank regulations, supervision, market structure, and bank characteristics on individual bank ratings: A crosscountry analysis. Review of Quantitative Finance and Accounting 27(4), 403-438.

Reinhart, C., 2012. The return of financial repression in public debt, monetary policy and financial stability. Banque de France, Financial Stability Review 16.

Reinhart, C., Rogoff, S.K., 2008. Is the 2007 US sub-prime financial crisis so different? An international historical comparison. American Economic Review 98(2), 339-44.

Schularick, M., Taylor, A., 2012. Credit booms gone bust: Monetary policy, leverage cycles, and financial crises, 1870-2008. American Economic Review 102(2), 1029-61. 
Table 1.

The effects of interest rate regulation on crises probabilities

\begin{tabular}{|c|c|c|c|}
\hline \multirow{3}{*}{ Dependent Variable: Crisis Onset } & \multicolumn{3}{|c|}{ Regression Stages } \\
\hline & $\begin{array}{c}\text { Baseline } \\
\text { Model }\end{array}$ & \multicolumn{2}{|c|}{ Interest Rate Regulation } \\
\hline & & With Capital & Parsimonious \\
\hline & (1) & (2) & (3) \\
\hline Interest Rate Regulation (-1) & - & $\begin{array}{l}-0.148 \\
(0.130)\end{array}$ & $\begin{array}{l}-0.226 \\
(0.000)\end{array}$ \\
\hline Liquidity Ratio (-1) & $\begin{array}{l}-0.131 \\
(0.000)\end{array}$ & $\begin{array}{l}-0.099 \\
(0.007)\end{array}$ & $\begin{array}{l}-0.093 \\
(0.008)\end{array}$ \\
\hline$\Delta$ Real House Price $(-3)$ & $\begin{array}{c}0.096 \\
(0.004)\end{array}$ & $\begin{array}{c}0.105 \\
(0.002)\end{array}$ & $\begin{array}{c}0.116 \\
(0.000)\end{array}$ \\
\hline Current Account Balance (\% of GDP) (-1) & $\begin{array}{l}-0.156 \\
(0.018)\end{array}$ & $\begin{array}{l}-0.121 \\
(0.074)\end{array}$ & - \\
\hline Capital Adequacy Ratio (-1) & $\begin{array}{l}-0.288 \\
(0.000)\end{array}$ & $\begin{array}{l}-0.106 \\
(0.450)\end{array}$ & - \\
\hline AUC & 0.785 & 0.785 & 0.774 \\
\hline
\end{tabular}

Note: Coefficient (probability). Estimation Period: 1980 - 2008.

Table 2.

Interaction between interest rate regulation and capital adequacy

\begin{tabular}{|l|c|c|}
\hline \multicolumn{1}{|c|}{ Dependent Variable: Crisis Onset } & \multicolumn{2}{|c|}{ Regression Stages } \\
\cline { 2 - 3 } & Baseline & \\
& Model & Interaction \\
\hline Interest Rate Regulation*Capital Adequacy Ratio (-1) & - & -0.031 \\
\hline Liquidity Ratio (-1) & & $(0.000)$ \\
\hline Real House Price (-3) & $\begin{array}{c}-0.131 \\
(0.000)\end{array}$ & $\begin{array}{c}-0.13 \\
(0.000)\end{array}$ \\
\hline Current Account Balance (\% of GDP) (-1) & $\begin{array}{c}0.096 \\
(0.004)\end{array}$ & $\begin{array}{c}0.101 \\
(0.003)\end{array}$ \\
\hline Capital Adequacy Ratio (-1) & $\begin{array}{c}-0.156 \\
(0.018)\end{array}$ & $\begin{array}{c}-0.158 \\
(0.018)\end{array}$ \\
\hline AUC & $\begin{array}{c}-0.288 \\
(0.000)\end{array}$ & - \\
\hline
\end{tabular}

Note: Coefficient (probability). Estimation Period: 1980 - 2008. 
Table 3.

Relative contributions of variables to crisis probabilities

\begin{tabular}{lcccc}
\hline & \multicolumn{4}{c}{ Variables } \\
\cline { 2 - 5 } & $\begin{array}{l}\text { Interest rate } \\
\text { liberalization }\end{array}$ & Capital & Liquidity & Real house prices \\
\hline $1980 \mathrm{~s}$ & -0.01 & 0.1 & -0.05 & 0.89 \\
$1990 \mathrm{~s}$ & 0 & 1.18 & 0.02 & -0.27 \\
$2000 \mathrm{~s}$ & 0.04 & -0.03 & 0.38 & 0.55 \\
\hline
\end{tabular}

Source: Authors' calculations.

Table 4.

Results for country elimination tests

\begin{tabular}{|c|c|c|c|c|c|c|c|}
\hline Interest Rate Regulation & $\begin{array}{c}\text { UK } \\
\text { not } \\
\text { included }\end{array}$ & $\begin{array}{c}\text { US } \\
\text { not } \\
\text { included }\end{array}$ & $\begin{array}{c}\text { Japan } \\
\text { not } \\
\text { included }\end{array}$ & $\begin{array}{c}\text { US \& } \\
\text { Japan } \\
\text { not } \\
\text { included }\end{array}$ & $\begin{array}{l}\text { Norway } \\
\text { not } \\
\text { included }\end{array}$ & $\begin{array}{l}\text { Finland } \\
\text { not } \\
\text { included }\end{array}$ & $\begin{array}{l}\text { Sweden } \\
\text { not } \\
\text { included }\end{array}$ \\
\hline-0.226 & -0.196 & -0.167 & -0.250 & -0.189 & -0.315 & -0.363 & -0.225 \\
\hline$(0.000)$ & $(0.002)$ & $(0.190)$ & $(0.014)$ & $(0.003)$ & $(0.002)$ & $(0.000)$ & $(0.006)$ \\
\hline-0.093 & -0.084 & -0.088 & -0.094 & -0.090 & -0.098 & -0.110 & -0.092 \\
\hline$(0.008)$ & $(0.024)$ & $(0.013)$ & $(0.007)$ & $(0.011)$ & $(0.005)$ & $(0.002)$ & $(0.009)$ \\
\hline 0.116 & 0.114 & 0.121 & 0.116 & 0.121 & 0.119 & 0.129 & 0.116 \\
\hline$(0.000)$ & $(0.000)$ & $(0.000)$ & $(0.000)$ & $(0.000)$ & $(0.000)$ & $(0.000)$ & $(0.000)$ \\
\hline $\begin{array}{l}\text { Final panel (b) Interaction } \\
\text { Interest Rate Regulation * } \\
\text { Capital Adequacy }\end{array}$ & $\begin{array}{c}\text { UK } \\
\text { not } \\
\text { included }\end{array}$ & $\begin{array}{c}\text { US } \\
\text { not } \\
\text { included }\end{array}$ & $\begin{array}{c}\text { Japan } \\
\text { not } \\
\text { included }\end{array}$ & $\begin{array}{c}\text { US \& } \\
\text { Japan } \\
\text { not } \\
\text { included }\end{array}$ & $\begin{array}{l}\text { Norway } \\
\text { not } \\
\text { included }\end{array}$ & $\begin{array}{l}\text { Finland } \\
\text { not } \\
\text { included }\end{array}$ & $\begin{array}{l}\text { Sweden } \\
\text { not } \\
\text { included }\end{array}$ \\
\hline $\begin{array}{l}-0.031 \\
(0.000)\end{array}$ & $\begin{array}{l}-0.028 \\
(0.002)\end{array}$ & $\begin{array}{l}-0.024 \\
(0.005)\end{array}$ & $\begin{array}{l}-0.028 \\
(0.021)\end{array}$ & $\begin{array}{l}-0.026 \\
(0.003)\end{array}$ & $\begin{array}{l}-0.026 \\
(0.023)\end{array}$ & $\begin{array}{l}-0.033 \\
(0.001)\end{array}$ & $\begin{array}{l}-0.024 \\
(0.015)\end{array}$ \\
\hline $\begin{array}{l}-0.130 \\
(0.000)\end{array}$ & $\begin{array}{l}-0.116 \\
(0.006)\end{array}$ & $\begin{array}{l}-0.102 \\
(0.005)\end{array}$ & $\begin{array}{l}-0.125 \\
(0.001)\end{array}$ & $\begin{array}{l}-0.115 \\
(0.001)\end{array}$ & $\begin{array}{l}-0.120 \\
(0.001)\end{array}$ & $\begin{array}{l}-0.140 \\
(0.001)\end{array}$ & $\begin{array}{l}-0.111 \\
(0.003)\end{array}$ \\
\hline 0.101 & 0.101 & 0.117 & 0.102 & 0.111 & 0.100 & 0.101 & 0.104 \\
\hline$(0.003)$ & $(0.003)$ & $(0.001)$ & $(0.003)$ & $(0.002)$ & $(0.003)$ & $(0.004)$ & $(0.002)$ \\
\hline-0.158 & -0.147 & -0.123 & -0.157 & -0.146 & -0.155 & -0.165 & -0.154 \\
\hline$(0.018)$ & $(0.037)$ & $(0.078)$ & $(0.019)$ & $(0.033)$ & $(0.017)$ & $(0.017)$ & $(0.020)$ \\
\hline
\end{tabular}

Note: Coefficient (probability). Estimation Period: 1980 - 2008. 
Table 5.

Results for the second lag

\begin{tabular}{lcc}
\hline & $\begin{array}{c}\text { Interest Rate Regulation } \\
* \text { Capital Adequacy }\end{array}$ & Interest Rate Regulation \\
\hline Interest Rate Regulation (-2) & - & -0.228 \\
& - & $(0.000)$ \\
Liquidity Ratio (-2) & -0.126 & -0.088 \\
& $(0.000)$ & $(0.008)$ \\
D Real House (-3) & 0.102 & 0.117 \\
& $(0.002)$ & $(0.000)$ \\
Interest Rate Regulation*Capital & -0.031 & - \\
Adequacy Ratio (-2) & $(0.000)$ & - \\
Current Account Balance (\% of & -0.185 & - \\
GDP) (-2) & $(0.012)$ & - \\
\hline
\end{tabular}

Note: Coefficient (probability). Estimation Period: 1980 - 2008.

Table 6.

Results for the impact of sub-prime crisis

\begin{tabular}{lcc}
\hline & $\begin{array}{c}\text { Interest Rate Regulation } \\
* \text { Capital Adequacy }\end{array}$ & \begin{tabular}{c} 
Interest Rate Regulation \\
\hline Interest Rate Regulation (-1)
\end{tabular} \\
& - & -0.330 \\
Liquidity Ratio (-1) & -0.084 & $(0.000)$ \\
& $(0.018)$ & -0.053 \\
D Real House (-3) & 0.097 & $(0.1464)$ \\
& $(0.019)$ & 0.110 \\
Interest Rate Regulation*Capital & -0.055 & $(0.003)$ \\
Adequacy Ratio (-1) & $(0.000)$ & - \\
Current Account Balance (\% of & -0.350 & - \\
GDP) (-1) & $(0.010)$ & - \\
\hline
\end{tabular}

Note: Coefficient (probability). Estimation Period: 1980 - 2006. 


\section{Appendix A}

A.1 The effects of interest rate regulation on crises probabilities

\begin{tabular}{|c|c|c|c|c|c|c|c|c|c|c|}
\hline \multirow{2}{*}{ Dependent Variable: Crisis Onset } & \multicolumn{10}{|c|}{ Regression Stage } \\
\hline & 1 & 2 & 3 & 4 & 5 & 6 & 7 & 8 & 9 & 10 \\
\hline Interest Rate Regulation (-1) & $\begin{array}{l}-0.287 \\
(0.196) \\
\end{array}$ & $\begin{array}{l}-0.287 \\
(0.194) \\
\end{array}$ & $\begin{array}{l}-0.283 \\
(0.199) \\
\end{array}$ & $\begin{array}{l}-0.245 \\
(0.223) \\
\end{array}$ & $\begin{array}{l}-0.268 \\
(0.148) \\
\end{array}$ & $\begin{array}{l}-0.267 \\
(0.149) \\
\end{array}$ & $\begin{array}{l}-0.266 \\
(0.150) \\
\end{array}$ & $\begin{array}{l}-0.148 \\
(0.130) \\
\end{array}$ & $\begin{array}{l}-0.212 \\
(0.000) \\
\end{array}$ & $\begin{array}{l}-0.226 \\
(0.000) \\
\end{array}$ \\
\hline Liquidity Ratio (-1) & $\begin{array}{l}-0.112 \\
(0.011)\end{array}$ & $\begin{array}{l}-0.112 \\
(0.011)\end{array}$ & $\begin{array}{l}-0.114 \\
(0.009)\end{array}$ & $\begin{array}{l}-0.118 \\
(0.005)\end{array}$ & $\begin{array}{l}-0.117 \\
(0.005) \\
\end{array}$ & $\begin{array}{l}-0.107 \\
(0.005)\end{array}$ & $\begin{array}{l}-0.106 \\
(0.005)\end{array}$ & $\begin{array}{l}-0.099 \\
(0.007)\end{array}$ & $\begin{array}{l}-0.096 \\
(0.007)\end{array}$ & $\begin{array}{l}-0.093 \\
(0.008)\end{array}$ \\
\hline D Real House Price (-3) & $\begin{array}{l}0.117 \\
(0.002) \\
\end{array}$ & $\begin{array}{l}0.117 \\
(0.002) \\
\end{array}$ & $\begin{array}{l}0.117 \\
(0.002) \\
\end{array}$ & $\begin{array}{l}0.115 \\
(0.002) \\
\end{array}$ & $\begin{array}{l}0.116 \\
(0.001) \\
\end{array}$ & $\begin{array}{l}0.109 \\
(0.001) \\
\end{array}$ & $\begin{array}{l}0.107 \\
(0.002) \\
\end{array}$ & $\begin{array}{l}0.105 \\
(0.002) \\
\end{array}$ & $\begin{array}{l}0.103 \\
(0.002) \\
\end{array}$ & $\begin{array}{l}0.116 \\
(0.000) \\
\end{array}$ \\
\hline Current Account Balance (\% of GDP) (-1) & $\begin{array}{l}-0.104 \\
(0.219)\end{array}$ & $\begin{array}{l}-0.104 \\
(0.218)\end{array}$ & $\begin{array}{l}-0.108 \\
(0.195)\end{array}$ & $\begin{array}{l}-0.101 \\
(0.213)\end{array}$ & $\begin{array}{l}-0.108 \\
(0.157)\end{array}$ & $\begin{array}{l}-0.126 \\
(0.063)\end{array}$ & $\begin{array}{l}-0.124 \\
(0.067)\end{array}$ & $\begin{array}{l}-0.121 \\
(0.074)\end{array}$ & $\begin{array}{l}-0.103 \\
(0.087)\end{array}$ & \\
\hline Capital Adequacy Ratio (-1) & $\begin{array}{l}-0.102 \\
(0.525) \\
\end{array}$ & $\begin{array}{l}-0.103 \\
(0.503) \\
\end{array}$ & $\begin{array}{l}-0.106 \\
(0.49) \\
\end{array}$ & $\begin{array}{l}-0.1 \\
(0.508) \\
\end{array}$ & $\begin{array}{l}-0.107 \\
(0.473) \\
\end{array}$ & $\begin{array}{l}-0.129 \\
(0.366) \\
\end{array}$ & $\begin{array}{l}-0.123 \\
(0.389) \\
\end{array}$ & $\begin{array}{l}-0.106 \\
(0.450) \\
\end{array}$ & & \\
\hline Constant & $\begin{array}{l}1.006 \\
(0.683)\end{array}$ & $\begin{array}{l}1.008 \\
(0.682)\end{array}$ & $\begin{array}{l}1.077 \\
(0.657)\end{array}$ & $\begin{array}{l}0.647 \\
(0.771) \\
\end{array}$ & $\begin{array}{l}1.016 \\
(0.573) \\
\end{array}$ & $\begin{array}{l}1.194 \\
(0.502)\end{array}$ & $\begin{array}{l}1.302 \\
(0.461)\end{array}$ & & & \\
\hline$\Delta \mathrm{GDP}(-1)$ & $\begin{array}{l}0.077 \\
(0.573) \\
\end{array}$ & $\begin{array}{l}0.077 \\
(0.573) \\
\end{array}$ & $\begin{array}{l}0.078 \\
(0.571) \\
\end{array}$ & $\begin{array}{l}0.089 \\
(0.513) \\
\end{array}$ & $\begin{array}{l}0.083 \\
(0.54) \\
\end{array}$ & $\begin{array}{l}0.06 \\
(0.638) \\
\end{array}$ & & & & \\
\hline Budget Balance (\% of GDP) $(-1)$ & $\begin{array}{l}-0.034 \\
(0.692)\end{array}$ & $\begin{array}{l}-0.034 \\
(0.692)\end{array}$ & $\begin{array}{l}-0.038 \\
(0.652)\end{array}$ & $\begin{array}{l}-0.045 \\
(0.574)\end{array}$ & $\begin{array}{l}-0.045 \\
(0.578)\end{array}$ & & & & & \\
\hline Real Interest Rate (-1) & $\begin{array}{l}0.049 \\
(0.596) \\
\end{array}$ & $\begin{array}{l}0.049 \\
(0.596) \\
\end{array}$ & $\begin{array}{l}0.046 \\
(0.614) \\
\end{array}$ & $\begin{array}{l}0.019 \\
(0.777) \\
\end{array}$ & & & & & & \\
\hline Inflation $(-1)$ & $\begin{array}{l}-0.072 \\
(0.671) \\
\end{array}$ & $\begin{array}{l}-0.072 \\
(0.669) \\
\end{array}$ & $\begin{array}{l}-0.072 \\
(0.668) \\
\end{array}$ & & & & & & & \\
\hline M2 Money/ Forex Reserves (-1) & $\begin{array}{l}0 \\
(0.847) \\
\end{array}$ & $\begin{array}{l}0 \\
(0.846) \\
\end{array}$ & & & & & & & & \\
\hline$\Delta$ Domestic Credit $(-1)$ & $\begin{array}{l}0 \\
(0.991)\end{array}$ & & & & & & & & & \\
\hline AUC & 0.805 & 0.805 & 0.806 & 0.807 & 0.797 & 0.800 & 0.803 & 0.797 & 0.794 & 0.774 \\
\hline
\end{tabular}

Note: Coefficient (probability). Estimation Period: 1980 - 2008 
A.2 The effects of Interest Rate Regulation*Capital Adequacy on crises probabilities

\begin{tabular}{|c|c|c|c|c|c|c|c|c|c|c|}
\hline \multirow{2}{*}{ Dependent Variable: Crisis Onset } & \multicolumn{10}{|c|}{ Regression Stage } \\
\hline & 1 & 2 & 3 & 4 & 5 & 6 & 7 & 8 & 9 & 10 \\
\hline Interest Rate Regulation*Capital Adequacy Ratio (-1) & $\begin{array}{l}-0.125 \\
(0.418) \\
\end{array}$ & $\begin{array}{l}-0.123 \\
(0.418)\end{array}$ & $\begin{array}{l}-0.124 \\
(0.415)\end{array}$ & $\begin{array}{l}-0.074 \\
(0.13) \\
\end{array}$ & $\begin{array}{l}-0.067 \\
(0.143) \\
\end{array}$ & $\begin{array}{l}-0.071 \\
(0.092) \\
\end{array}$ & $\begin{array}{l}-0.069 \\
(0.097)\end{array}$ & $\begin{array}{l}-0.069 \\
(0.097) \\
\end{array}$ & $\begin{array}{l}-0.021 \\
(0.12) \\
\end{array}$ & $\begin{array}{l}-0.031 \\
(0.000) \\
\end{array}$ \\
\hline Liquidity Ratio (-1) & $\begin{array}{l}-0.113 \\
(0.011)\end{array}$ & $\begin{array}{l}-0.113 \\
(0.011)\end{array}$ & $\begin{array}{l}-0.115 \\
(0.009)\end{array}$ & $\begin{array}{l}-0.113 \\
(0.009)\end{array}$ & $\begin{array}{l}-0.117 \\
(0.005)\end{array}$ & $\begin{array}{l}-0.116 \\
(0.006)\end{array}$ & $\begin{array}{l}-0.106 \\
(0.006)\end{array}$ & $\begin{array}{l}-0.104 \\
(0.006)\end{array}$ & $\begin{array}{l}-0.108 \\
(0.007)\end{array}$ & $\begin{array}{c}-0.13 \\
(0.000) \\
\end{array}$ \\
\hline D Real House Price (-3) & $\begin{array}{l}0.121 \\
(0.001)\end{array}$ & $\begin{array}{l}0.121 \\
(0.001) \\
\end{array}$ & $\begin{array}{l}0.12 \\
(0.001)\end{array}$ & $\begin{array}{l}0.12 \\
(0.001)\end{array}$ & $\begin{array}{l}0.118 \\
(0.001)\end{array}$ & $\begin{array}{l}0.12 \\
(0.001)\end{array}$ & $\begin{array}{l}0.111 \\
(0.001)\end{array}$ & $\begin{array}{l}0.11 \\
(0.001)\end{array}$ & $\begin{array}{l}0.104 \\
(0.002)\end{array}$ & $\begin{array}{l}0.101 \\
(0.003) \\
\end{array}$ \\
\hline Current Account Balance (\% of GDP) (-1) & $\begin{array}{l}-0.112 \\
(0.197)\end{array}$ & $\begin{array}{l}-0.111 \\
(0.198)\end{array}$ & $\begin{array}{l}-0.115 \\
(0.178)\end{array}$ & $\begin{array}{l}-0.113 \\
(0.182)\end{array}$ & $\begin{array}{l}-0.105 \\
(0.199)\end{array}$ & $\begin{array}{l}-0.111 \\
(0.15)\end{array}$ & $\begin{array}{l}-0.132 \\
(0.052)\end{array}$ & $\begin{array}{l}-0.129 \\
(0.056)\end{array}$ & $\begin{array}{l}-0.14 \\
(0.043)\end{array}$ & $\begin{array}{l}-0.158 \\
(0.018)\end{array}$ \\
\hline Constant & $\begin{array}{l}-4.037 \\
(0.551)\end{array}$ & $\begin{array}{l}-4.002 \\
(0.552)\end{array}$ & $\begin{array}{l}-3.953 \\
(0.556)\end{array}$ & $\begin{array}{l}-1.642 \\
(0.165)\end{array}$ & $\begin{array}{l}-1.705 \\
(0.146)\end{array}$ & $\begin{array}{l}-1.58 \\
(0.13)\end{array}$ & $\begin{array}{l}-1.361 \\
(0.167)\end{array}$ & $\begin{array}{l}-1.248 \\
(0.191)\end{array}$ & $\begin{array}{l}-0.771 \\
(0.384)\end{array}$ & \\
\hline Capital Adequacy Ratio (-1) & $\begin{array}{l}1.091 \\
(0.46)\end{array}$ & $\begin{array}{l}1.083 \\
(0.461)\end{array}$ & $\begin{array}{l}1.089 \\
(0.458)\end{array}$ & $\begin{array}{l}0.604 \\
(0.234)\end{array}$ & $\begin{array}{l}0.541 \\
(0.261)\end{array}$ & $\begin{array}{l}0.575 \\
(0.211)\end{array}$ & $\begin{array}{l}0.53 \\
(0.237)\end{array}$ & $\begin{array}{l}0.537 \\
(0.23)\end{array}$ & & \\
\hline$\Delta \mathrm{GDP}(-1)$ & $\begin{array}{l}0.081 \\
(0.559)\end{array}$ & $\begin{array}{l}0.081 \\
(0.559)\end{array}$ & $\begin{array}{l}0.081 \\
(0.556)\end{array}$ & $\begin{array}{l}0.078 \\
(0.571)\end{array}$ & $\begin{array}{l}0.088 \\
(0.518)\end{array}$ & $\begin{array}{l}0.083 \\
(0.538)\end{array}$ & $\begin{array}{l}0.058 \\
(0.649)\end{array}$ & & & \\
\hline Budget Balance (\% of GDP) $(-1)$ & $\begin{array}{l}-0.043 \\
(0.617)\end{array}$ & $\begin{array}{l}-0.043 \\
(0.614) \\
\end{array}$ & $\begin{array}{l}-0.047 \\
(0.579)\end{array}$ & $\begin{array}{l}-0.042 \\
(0.613)\end{array}$ & $\begin{array}{l}-0.049 \\
(0.54)\end{array}$ & $\begin{array}{l}-0.05 \\
(0.54)\end{array}$ & & & & \\
\hline Real Interest Rate (-1) & $\begin{array}{l}0.044 \\
(0.637) \\
\end{array}$ & $\begin{array}{l}0.044 \\
(0.638) \\
\end{array}$ & $\begin{array}{l}0.041 \\
(0.657) \\
\end{array}$ & $\begin{array}{l}0.042 \\
(0.645) \\
\end{array}$ & $\begin{array}{l}0.015 \\
(0.818) \\
\end{array}$ & & & & & \\
\hline Inflation $(-1)$ & $\begin{array}{l}-0.062 \\
(0.722)\end{array}$ & $\begin{array}{l}-0.06 \\
(0.725)\end{array}$ & $\begin{array}{l}-0.062 \\
(0.719)\end{array}$ & $\begin{array}{l}-0.07 \\
(0.677)\end{array}$ & & & & & & \\
\hline Interest Rate Regulation (-1) & $\begin{array}{l}0.241 \\
(0.732)\end{array}$ & $\begin{array}{l}0.235 \\
(0.735)\end{array}$ & $\begin{array}{l}0.243 \\
(0.727)\end{array}$ & & & & & & & \\
\hline M2 Money/ Forex Reserves (-1) & $\begin{array}{l}0.000 \\
(0.81)\end{array}$ & $\begin{array}{l}0.000 \\
(0.813)\end{array}$ & & & & & & & & \\
\hline$\Delta$ Domestic Credit $(-1)$ & $\begin{array}{l}0.000 \\
(0.948) \\
\end{array}$ & & & & & & & & & \\
\hline AUC & 0.819 & 0.815 & 0.814 & 0.817 & 0.812 & 0.810 & 0.806 & 0.813 & 0.796 & 0.792 \\
\hline
\end{tabular}

Note: Coefficient (probability). Estimation Period: 1980 - 2008. 